\title{
Predictive value of serum uric acid levels for adverse perinatal outcomes in preeclampsia
}

\author{
Veena Bhagavan, Aadhishree Rao*, Ritu Sharma
}

\begin{abstract}
Department of Obstetrics and Gynaecology, A. J. Institute of Medical Sciences and Research Centre, Mangalore,
\end{abstract} Karnataka, India

Received: 31 December 2021

Accepted: 15 January 2022

\author{
*Correspondence: \\ Dr. Aadhishree Rao, \\ E-mail: aadhishree@gmail.com
}

Copyright: (c) the author(s), publisher and licensee Medip Academy. This is an open-access article distributed under the terms of the Creative Commons Attribution Non-Commercial License, which permits unrestricted non-commercial use, distribution, and reproduction in any medium, provided the original work is properly cited.

\begin{abstract}
Background: Hypertensive disorders of pregnancy affect 6-8\% of all pregnancies and along-with haemorrhage and infection, they form a complex triad, contributing immensely to maternal morbidity and mortality. Although exact aetiopathogenesis of pre-eclampsia is unknown, multiple factors have been implicated to have a role in it; the factors being abnormal placental implantation, endothelial dysfunction, maternal immunological tolerance, cardiovascular, genetic, nutritional and environmental factors. Increased uric acid concentration is one of the most pronounced clinical findings in preeclampsia. Hyperuricemia in preeclamptic women is primarily due to a reduction in glomerular filtration rate due to endothelial dysfunction. In this study we look to explore the relationship between elevated serum uric acid and the perinatal outcomes, especially the ability to predict adverse perinatal outcomes.

Methods: This was a hospital based retrospective study, conducted in A $\mathbf{J}$ institute of medical sciences and research centre, from January 2020 to December 2020. 75 study participants $>20$ weeks with diagnosed preeclampsia were chosen and their perinatal outcomes were measured. Chi square test and Fisher exact test was used to calculate $p>0.05$ was considered statistically significant.

Results: Mean gestational age at delivery for elevated serum uric acid was 36.8 with $\mathrm{SD}=2.57$ and those with normal uric acid levels is 38.43 with $\mathrm{SD}=0.89$. FGR was seen in 5 patients, among which $4(80 \%)$ had increased serum uric acid levels and $1(20 \%)$ had normal serum uric acid levels. Total number of neonates who had APGAR score $<7$ was 3 , among whom 2 neonates $(66.66 \%)$ were born to increased uric acid level mothers. Out of 74 neonates, total number of neonates who had NICU admission were 20, among whom 9 neonates (45\%) were born to mothers with increased serum uric acid levels.

Conclusions: The study concluded that elevated serum uric acid is significantly associated with adverse perinatal outcomes, like FGR, low birthweight, low APGAR score and increased NICU admissions, there was no significant association between elevated serum uric acid level and mode of delivery.
\end{abstract}

Keywords: Preeclampsia, Serum uric acid, Perinatal outcome

\section{INTRODUCTION}

Hypertensive disorders of pregnancy affect $6-8 \%$ of all pregnancies and along-with haemorrhage and infection, they form a complex triad, contributing immensely to maternal morbidity and mortality. ${ }^{1-3}$ Although exact aetiopathogenesis of pre-eclampsia is unknown, multiple factors have been implicated to have a role in it; the factors being abnormal placental implantation, endothelial dysfunction, maternal immunological tolerance, cardiovascular, genetic, nutritional and environmental factors. ${ }^{4}$ Increased uric acid concentration is one of the most pronounced clinical findings in preeclampsia. Hyperuricemia in preeclamptic women is primarily due to 
a reduction in glomerular filtration rate due to endothelial dysfunction. $^{5}$ In this study we look to explore the relationship between elevated serum uric acid and the perinatal outcomes, especially the ability to predict adverse perinatal outcomes.

Hypertensive disorders complicate 5 to 10 percent of all pregnancies, and together they are one member of the deadly triad-along with haemorrhage and infection-that contribute to the maternal morbidity and mortality. ${ }^{6}$ According to the WHO in developed countries $16 \%$ of maternal deaths were reported to be due to hypertensive disorders. ${ }^{7}$ Preeclampsia is associated with increased maternal and perinatal morbidity and mortality. Measurement during early pregnancy of various biological, biochemical, and biophysical markers implicated in preeclampsia syndrome pathophysiology has been proposed to predict its development. Uric acid is one of the earliest laboratory manifestations of preeclampsia. In preeclampsia, vasospasm and glomerular endotheliosis lead to reduction in renal perfusion and glomerular filtration. Renal function deteriorates in 2 stages: the first involves the impairment of tubular function and reduction in uric acid clearance and development of hyperuricemia. Later glomerular filtration becomes impaired and proteinuria develops. An increase in plasma urate is therefore an early sign in the evolution of preeclampsia. ${ }^{8}$ It has been cited as a better predictor of fetal risk than blood pressure. ${ }^{9}$ It identifies women in increased risk of adverse maternal and particularly fetal outcome. ${ }^{10}$ Serum uric acid levels rise later in pregnancy probably due to increased fetal production, decreased binding to albumin, and a decline in uric acid clearance. ${ }^{11,12}$ This study aims to determine the predictive value of serum uric acid for adverse perinatal outcomes in preeclampsia.

\section{METHODS}

It was a retrospective study conducted among singleton pregnancy who were diagnosed with preeclampsia after 20 weeks of gestation. It was conducted in the department of obstetrics and gynaecology, A J institute of medical science and research centre. The study period was from January 2020 to December 2020. All women who satisfied the inclusion criteria were included in the study. Total number of study participants were 75 .

\section{Selection criteria}

Inclusion criteria was age $>18$ years, singleton pregnancy of more than 20 weeks, she should be a diagnosed preeclampsia. Exclusion criteria were pregnant women $<20$ weeks, patients with medical conditions like chronic hypertension diabetes mellitus thyrotoxicosis, renal disease, hepatic disorders and gout. Multiple gestation, uterine anomalies and alcohol and drug abuse was excluded.

Serum uric acid levels considered were $2^{\text {nd }}$ trimester 2.4 $4.9 \mathrm{mg} / \mathrm{dl}, 3^{\text {rd }}$ trimester $3.1-6.3 \mathrm{mg} / \mathrm{dl}$.
Chi square test, Fisher's test and other appropriate statistical test were used for finding the association between the factors, $\mathrm{p}<0.05$ was considered significant.

Maternal outcomes in terms of period of gestation at delivery, mode of delivery and foetal outcomes in terms of FGR, birth weight, APGAR score and NICU admissions were noted.

\section{RESULTS}

The characteristics of the study population; number of patients with age $<20$ years were $3(4 \%)$, age $21-25$ years were 15 (20\%), 26-30 years were 35 (46.6\%), 31-35 years were $20(26.6 \%)$ and $>35$ years were $2(2.6 \%)$. Maximum number of patients belonged to age group of 26-35 years (46.6\%) (Figure 1).

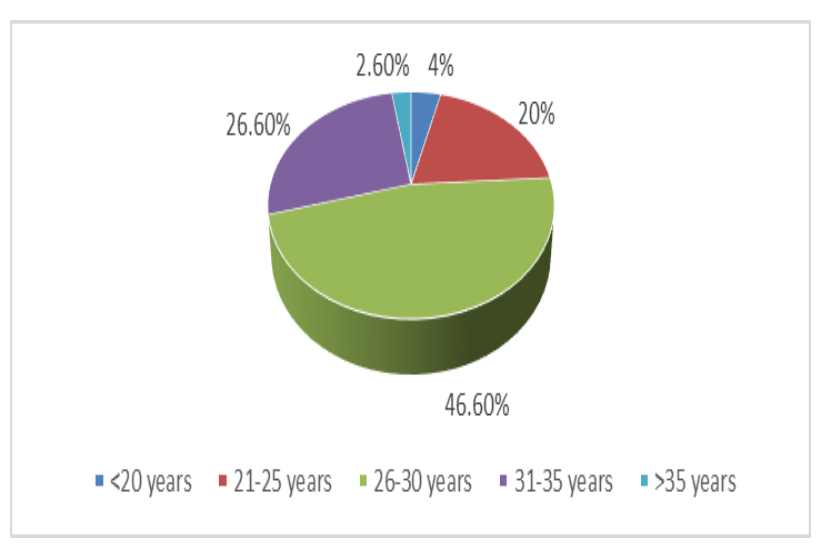

Figure 1: Age distribution.

Majority of the participants belonged to lower middle class $24(32 \%)$. Followed by upper lower class $16(21.33 \%)$. Least belonged to upper class $5(6.66 \%)$.

Parity status in the study group, most of the study participants were primigravida $27(36 \%)$, second gravida were $23(31.66 \%)$, gravida 3 were $17(23.66 \%)$. Lastly more than gravida 4 were $8(10.66 \%)$.

The average serum uric acid level was $4.7 \mathrm{mg} / \mathrm{dl}$, and total number of women in the study group who had normal levels were $60(80 \%)$, and the number of patients who had increased levels were 15 (20\%).

Number of patients who delivered at more than 37 weeks were $70(93.33 \%)$, and who delivered less than 37 weeks were $5(6.66 \%)$.

The number of patients who delivered vaginally were 39 (52\%), emergency LSCS were $23(30.66 \%)$ and elective LSCS were $13(17.33 \%)$. Out of the women who delivered vaginally 15 patients $(20 \%)$ were induced labour (Figure 2). 


\section{Mode of Delivery}

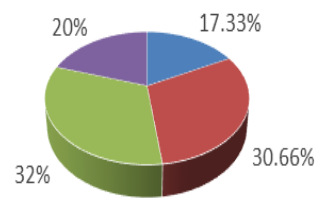

- Elective LSCS - Emergency LSCS

- Spontaneous Vaginal delivery • Induced Vaginal Delivery

Figure 2: Mode of delivery.

Total number of patients who had preterm delivery are 6 , among which 4 patients $(66.66 \%)$ had elevated serum uric acid levels and 2 patients $(33.33 \%)$ had normal uric acid levels. This showed significant association with $\mathrm{p}=0.0028$ (Table 1).

Table 1: Demographic data.

\begin{tabular}{|lll|l|}
\hline \multirow{2}{*}{ Sociodemographic data } & Number & $\begin{array}{l}\text { Percentage } \\
(\%)\end{array}$ \\
\hline \multirow{3}{*}{ Age (Years) } & $<18$ & 3 & 5 \\
\cline { 2 - 4 } & $18-35$ & 61 & 80.5 \\
\cline { 2 - 4 } Educational & $>35$ & 11 & 14.5 \\
\cline { 2 - 4 } status & Illiterate & 34 & 45 \\
\hline \multirow{2}{*}{ Occupation } & Primary & 30 & 40 \\
\cline { 2 - 4 } & Secondary & 11 & 15 \\
\hline \multirow{3}{*}{ Parity } & Professional & 20 & 27 \\
\hline & 0 & 13 & 17.5 \\
\cline { 2 - 4 } & 1 & 26 & 34.5 \\
\cline { 2 - 4 } & $2-4$ & 35 & 46.5 \\
\hline
\end{tabular}

The average gestational age in weeks in the patients who had elevated serum uric acid was 36.8 with $\mathrm{SD}=2.57$, those with normal uric acid levels is 38.43 with $\mathrm{SD}=0.89$ with a $\mathrm{p}=0.00193$ which was statistically significant (Table 2).

Table 2: Relationship between serum uric acid level and time of delivery.

\begin{tabular}{|llll}
$\begin{array}{l}\text { Serum uric } \\
\text { acid levels }\end{array}$ & $\begin{array}{l}\text { Preterm }(<37 \\
\text { weeks })(\%)\end{array}$ & $\begin{array}{l}\text { Term }(>37 \\
\text { weeks })(\%)\end{array}$ & Total \\
\hline Increased & $4(66.66)$ & $11(15.94)$ & 15 \\
\hline Normal & $2(33.33)$ & $58(84.05)$ & 60 \\
\hline Total & 6 & 69 & 75 \\
\hline
\end{tabular}

$\mathrm{P}=0.00288^{*}$

Among 15 patients with increased levels of uric acid, 8 patients $(53.3 \%)$ had vaginal delivery and 7 had cesarean section $(46.6 \%)$ (Table 3$)$. The results were not statistically significant. The patients who had normal levels of serum uric acid were 60 , among them 31 patients $(51.66 \%)$ had normal delivery and $29(48.33 \%)$ had cesarean section.
Table 3: Average gestational age at delivery compared to serum uric acid level.

\begin{tabular}{|lll|}
\hline $\begin{array}{l}\text { Serum uric } \\
\text { acid levels }\end{array}$ & $\begin{array}{l}\text { Average } \\
\text { gestational age }\end{array}$ & $\begin{array}{l}\text { Standard } \\
\text { deviation }\end{array}$ \\
\hline Increased & 36.8 weeks & 2.57 \\
\hline Normal & 38.43 weeks & 0.89 \\
\hline
\end{tabular}

$\mathrm{P}=0.00193^{*}$

Total number of patients who had FGR was 5, among which 4 patients $(80 \%)$ had increased serum uric acid levels and 1 patient (20\%) had normal serum uric acid levels, with $\mathrm{p}=0.004919$ being statistically significant (Table 4).

Table 4: Relationship between serum uric acid level and mode of delivery.

\begin{tabular}{|llll|}
\hline $\begin{array}{l}\text { Serum uric } \\
\text { acid levels }\end{array}$ & $\begin{array}{l}\text { Vaginal } \\
\text { delivery }\end{array}$ & $\begin{array}{l}\text { Caesarean } \\
\text { section }\end{array}$ & Total \\
\hline Increased & 8 & 7 & 15 \\
\hline Normal & 31 & 29 & 60 \\
\hline Total & 39 & 36 & 75 \\
\hline
\end{tabular}

$\mathrm{P}=0.907$ (not significant).

Total number of patients who had babies of birth weight $<2.5 \mathrm{~kg}$ was 10 , among whom 5 patients $(50 \%)$ patients had increased serum uric acid levels (Table 5). There was significant association between low birth weight and elevated serum uric acid levels with $\mathrm{p}=0.01084$.

Table 5: Relationship between serum uric acid level and FGR.

\begin{tabular}{|llll|}
\hline $\begin{array}{l}\text { Serum uric } \\
\text { acid levels }\end{array}$ & $\begin{array}{l}\text { FGR present } \\
(\%)\end{array}$ & $\begin{array}{l}\text { FGR absent } \\
(\%)\end{array}$ & Total \\
\hline Increased & $4(80)$ & $11(15.71)$ & 15 \\
\hline Normal & $1(20)$ & $59(84.29)$ & 60 \\
\hline Total & $5(100)$ & $70(100)$ & 75 \\
\hline
\end{tabular}

$\mathrm{P}=0.004919^{*}$

Total number of neonates who had APGAR score $<7$ at 5 minutes were 3 , among whom 2 neonates $(66.66 \%)$ were born to increased uric acid level mothers. One patient had IUD among the study participants. The $\mathrm{p}=0.03$ and was statistically significant (Table 6).

Table 6: Relationship between serum uric acid levels and birth weight of babies.

\begin{tabular}{|llll|}
\begin{tabular}{|l} 
Serum uric \\
acid levels
\end{tabular} & $\begin{array}{l}\text { Birth } \\
\text { weight }<2.5 \\
\text { kg }(\%)\end{array}$ & $\begin{array}{l}\text { Birth } \\
\text { weight }>2.5 \\
\text { kg }\end{array}$ & Total \\
\hline Increased & $5(50)$ & 10 & 15 \\
\hline Normal & $5(50)$ & 55 & 60 \\
\hline Total & 10 & 65 & 75 \\
\hline
\end{tabular}

$\mathrm{P}=0.01084 *$

Out of 74 neonates, total number of neonates who had NICU admission were 20, among whom 9 neonates $(45 \%)$ 
were born to mothers with increased serum uric acid levels. The $\mathrm{p}=0.002$ which was statistically significant (Table 7).

\section{Table 7: Relationship of serum uric acid levels and} APGAR score (5 ${ }^{\text {th }}$ minute).

\begin{tabular}{|llll|}
$\begin{array}{l}\text { Serum uric } \\
\text { acid levels }\end{array}$ & $\begin{array}{l}\text { APGAR } \\
\text { score }<7(\%)\end{array}$ & $\begin{array}{l}\text { APGAR } \\
\text { score }>7(\%)\end{array}$ & Total \\
\hline Increased & $2(66.66)$ & $12(16.9)$ & 14 \\
\hline Normal & $1(33.33)$ & $59(83.09)$ & 60 \\
\hline Total & 3 & 71 & 74 \\
\hline
\end{tabular}

$\mathrm{P}=0.0311^{*}$

Table 8: Relationship between uric acid levels and NICU admissions.

\begin{tabular}{|llll}
$\begin{array}{l}\text { Serum uric } \\
\text { acid levels }\end{array}$ & $\begin{array}{l}\text { NICU } \\
\text { admission } \\
\text { present }(\%)\end{array}$ & $\begin{array}{l}\text { NICU } \\
\text { admission } \\
\text { absent }(\%)\end{array}$ & Total \\
\hline Increased & $9(45)$ & $5(9.25)$ & 14 \\
\hline Normal & $11(55)$ & $49(90.75)$ & 60 \\
\hline Total & 20 & 54 & 74 \\
\hline
\end{tabular}

$\mathrm{P}=0.002 *$

\section{DISCUSSION}

The present study was a cross sectional study conducted among pregnant women to determine the serum uric acid levels and their correlation with maternal outcome and fetal outcome.

The total number of patients in this study group was 75, who were primigravidas and multigravidas with gestational age >20 weeks and who were diagnosed preeclampsia.

In the current study, majority of patients belonged to the age group of 25-30 years of age. The mean age of study participants was 28.49 years with a standard deviation of 4.19 years. A study done by Yuquan et al reported that the mean age of study participants was 30.3 years with $\mathrm{SD}=5.8 .{ }^{13}$ Similarly, Bellomo et al found that mean age in their study participants was 30.3 years with $\mathrm{SD}=4.1{ }^{14} \mathrm{~A}$ study done by Enaruna et al reported that the mean age in their study group was 28.09 years with $\mathrm{SD}=5.5$ and majority of the patients belonged to age group between 2029 years. ${ }^{15}$

According to modified Kuppuswamy classification majority of patients in our study group belonged to lower middle $(32 \%)$ class followed by lower socioeconomic class $(26.6 \%)$.

In the current study majority of patients were primigravidas (36\%) compared with second and third gravida. Similar results were found in a study done by Kooffreh in which majority of patients were primigravidas. ${ }^{16}$ Similar result was seen in a study done by
Yuquan et al where majority of patients who had hypertension were primigravida. ${ }^{13}$

The present study found that average serum uric acid level was $4.7 \mathrm{mg} / \mathrm{dl}$ with $\mathrm{SD}=1.21$. Study done by Yuquan et al also found similar results of average serum uric acid levels of $4.89 \mathrm{mg} / \mathrm{al}$ with $\mathrm{SD}=0.20 .{ }^{13}$ Urato et al found higher levels of average serum uric acid of $5-6 \mathrm{mg} / \mathrm{dl}$ in their study. ${ }^{17}$

According to study done by Yuquan et al they found out the average gestational age at the time of delivery was 36.4 weeks with $\mathrm{SD}=3.5 .{ }^{13}$ In a study done by Livingston the average gestational age at the time of delivery was 37 weeks. ${ }^{18}$ According to study done by Hawkins et al the average gestational age at the time of delivery was 36.4 weeks. ${ }^{19}$

In the current study $52 \%$ of patients delivered vaginally; among which $32 \%$ had spontaneous labor and $20 \%$ patients delivered following induction of labor. The percentage of patients who underwent LSCS were $47.99 \%$ In a study done by Bellomo et al. ${ }^{14}$ Cesarean section rates were $39 \%$ and was less compared to our study results.

In our study the average birth weight of the neonates was $2.88 \mathrm{~kg}$ with $\mathrm{SD}=0.48$, and $84 \%$ of neonates were between $2.5-3.5 \mathrm{~kg}$. In a study done by Bellomo et al the average birth weight of the neonates was $3060 \mathrm{gm}$ with $\mathrm{SD}=740$ gm. ${ }^{14}$

In our study 1 patient had IUD following an abruption. Hence analysis considered 74 neonates, $96 \%$ neonates had APGAR score 7-10. NICU admissions was required in $72.9 \%$ of neonates.

In our study when comparing the relation of serum uric acid level and gestational age at delivery, the average gestational age at delivery with elevated uric acid levels was 36.8 weeks with a $\mathrm{SD}=2.57$ weeks compared to 38.43 weeks gestational age at delivery when the uric acid levels were normal. Here $\mathrm{p}=0.00193$ which was statistically significant.

There was no significant correlation between serum uric acid level and the mode of delivery. The $52 \%$ had vaginal delivery and $48 \%$ had cesarean section for various indications.

In our study 5 patients had FGR among which 4 patients had elevated serum uric acid levels. Hence was p being statistically significant. In the study conducted by Bellomo et al there was significant relationship between elevated serum uric acid levels and SGA with $\mathrm{p}=0.02 .{ }^{14}$ In our study there was statistically significant correlation between serum uric acid and and average birth weight of the baby with $\mathrm{p}-0.000357$, and NICU admissions with $\mathrm{p}$ value 0.002 which could be explained because of antenatal complications like IUGR. But there was no significant 
association between serum uric acid levels and APGAR scores.

The study had few limitations like a small sample size and the patient demography is for a tertiary care centre. However larger sample size with a prospective study design can detect and be useful for predicting adverse perinatal outcomes.

\section{CONCLUSION}

The key findings of this study are that maternal serum uric acid level is an important parameter in predicting low birth weight, presence of FGR, low APGAR score and increased NICU admissions in women with hypertensive disorder of pregnancy. It can prove to be a useful aid in predicting neonatal morbidity.

\section{ACKNOWLEDGEMENTS}

The authors would like to thanks to colleagues and resident doctors who were supporting this study.

\section{Funding: No funding sources}

Conflict of interest: None declared

Ethical approval: The study was approved by the Institutional Ethics Committee

\section{REFERENCES}

1. Kamath S. Hypertension in pregnancy. JAPL. 2006;54:269-70.

2. Cunningham FG, Leveno KJ, Bloom SL. Chapter 40. Hypertensive disorders. In: Williams Obstetrics $\left(24^{\text {th }}\right.$ edn). New York, Mc Graw-Hill. 2014;728- 79.

3. American College of Obstetrician and Gynecologists. Women's Health Care Physicians. Hypertension in Pregnancy. Washington, DC. Chapter-2, Establishing the Diagnosis of Preeclampsia and Eclampsia. 2013;17-21.

4. Qublan H, Ammarin V, Bataineh O, Al-Shraideh Z, Tahat Y, Awamleh I et al. Lactic dehydrogenase as a biochemical marker of adverse pregnancy outcome in severe pre-eclampsia. Int Med J Exp Clin Res. 2005;11(8):CR393-7.

5. Ryu A, Cho NJ, Kim YS, Lee EY. Predictive value of serum uric acid levels for adverse perinatal outcomes in preeclampsia. Medicine (Baltimore). 2019;98(18):e15462.

6. Martin. Chapter 40: Hypertensive disorders. Williams Obstetrics. 24th ed. New York: Mc Graw-Hill; 2014: 747
7. Khan KS, Wojdyla D, Say L. WHO analysis of causes of maternal death: A systematic review. Lancet 2006;367:1066.

8. Redman CWA, Beilin LJ, Bonnar J, Wilkinson RH. Plasma urate measurements in predicting fetal deaths in Hypertensive pregnancies. Lancet. 1976;26.

9. Chesley LC. Diagnosis of preeclampsia. Obstet. Gynecol. 1985;65:423-5.

10. Hawkins TL, Roberts JM, Mangos GJ, Davis GK, Roberts LM, Brown MA. Plasma Uric acid remains a marker of poor outcome in hypertensive pregnancy: retrospective cohort study. BJOG. 2012;119(4):48492.

11. Foy RA. Uric acid in pregnancy and precclampsia: an alternative hypothesis. Aust NZ J Obstet Gynaecol. 1990;30(2):141/2.

12. Conde-Agudelo A, Lede R, Belizean J. Evaluation methods used in the prediction of hypertensive disorders of pregnancy. Obstet Gynecol Surv. 1994;49(3);210-22.

13. Yuquan WU, Fraser WD, Loo ZC. Association of uric acid with progression to preeclamsia and development of adverse conditions in Gestational hypertensive pregnancies. Am J Hypertens. 2012;25(6):711-7.

14. Bellomo G, Venanzi S, Saronio P, Verdure C, Luca P. Prognostic Significance of Serum uric acid in Women with Gestational hypertension. Hypertension. 2011;58(4):704-8.

15. Enaruna NO, Idemudia JO, Aikoriogie PI. Serum lipid profile and uric acid levels in preeclampsia in university of benin teaching hospital. Niger Med J. 2014;55(5):423-7.

16. Kooffreh ME, Ekott M, Ekpoudom DO. The prevalence of preeclampsia among pregnant women in the university of Calabar teaching hospital Calabar. Saudi J Health Sci. 2014;3(3):133-6.

17. Urato AC, Bond B, Strohsnitter WC. Admission uric acid levels and length of expectant management in preterm preeclampsia. J Perinatol. 2012;32(10):75762.

18. Hawkins TA, Robert JM, Mangos JC, Davis GK, Robert LM, Brown MA. Plasma uric acid remains a marker of poor outcome in hypertensive pregnant a prospective cohort study. BJOG. 2012;119:484-92.

19. Livingston JR, Payne B, Brown M, Roberts JM. Uric acid as a predictor of adverse maternal and perinatal outcomes in women hospitalised with preeclampsia. J Obstet Gynaecol Can. 2014;36(10)870-7.

Cite this article as: Bhagavan V, Rao A, Sharma R. Predictive value of serum uric acid levels for adverse perinatal outcomes in preeclampsia. Int J Reprod Contracept Obstet Gynecol 2022;11:400-4. 